\title{
EQUALITY AND AUTONOMY IN FIRST AMENDMENT JURISPRUDENCE
}

\author{
Robert Post*
}

Liberalism Divided: Freedom of Speech and the Many Uses of State Power. By Owen Fiss. Boulder: Westview Press. 1996. Pp. vii, 192. \$17.95.

Brown v. Board of Education, ${ }^{1}$ as Owen Fiss ${ }^{2}$ correctly observes in the introduction to Liberalism Divided: Freedom of Speech and the Many Uses of State Power, spurred a "revolution in American law" by "claiming a place for equality as central as that for liberty" (p. 4). Fiss's own work is inseparably connected to that revolution. Inspired by the Warren Court's commitment to the promise of Brown, Fiss produced an unforgettable body of scholarship that profoundly enriched our understanding of the values of egalitarianism and of the role of courts in achieving those values.

In the late 1980s Fiss began to turn his attention away from the Equal Protection Clause and toward the First Amendment. Liberalism Divided collects essays that Fiss has published on issues of freedom of speech during the past decade. Several of the essays are deservedly famous and influential. They forcefully express the same egalitarian sensibility that had informed Fiss's earlier work. In this respect, Liberalism Divided exemplifies the collision between equality and liberty that has so conspicuously characterized recent First Amendment scholarship.

I should confess at the outset of this review that Owen Fiss has long been my beau ideal of an American law professor. He was my mentor when I was a student, and ever since I have found inspiration in his generosity, his integrity, his luminous and encompassing intelligence. That is not to say, however, that I agree with Fiss's interpretation of the First Amendment. The recent infiltration of First Amendment jurisprudence by modes of analysis derived from equal protection doctrine has been, in my view, largely unfortu-

* Alexander F. \& May T. Morrison Professor of Law, Boalt Hall, University of California at Berkeley. A.B. 1969, Harvard; J.D. 1977, Yale; Ph.D. 1980, Harvard. - Ed. Many thanks to Jack Balkin, Jesse Choper, Meir Dan-Cohen, Stanley Fish, Owen Fiss, Don Herzog, Morry Lipson, Brett McDonnell, Frank Michelman, Paul Mishkin, Scott Powe, Eric Rakowski, Sam Scheffler, Reva Siegal, Jan Vetter and James Weinstein for their very helpful comments.

1. 347 U.S. 483 (1954).

2. Sterling Professor of Law, Yale University. 
nate. ${ }^{3}$ Because Fiss is so deeply committed to these modes of analysis, Liberalism Divided provides a perfect occasion for assessing some of the implications of this far-reaching development in First Amendment scholarship.

I.

The essays in Liberalism Divided address a large array of controversial issues in which the new egalitarian First Amendment scholarship has challenged traditional understandings. These issues range from the regulation of pornography and hate speech, to guarantees of public access to the media, to reform of campaign financing. With respect to each of these issues Fiss's commitment to egalitarian virtues is overriding. He can barely restrain his admiration for equal protection jurisprudence as "the taproot of modern law" (p. 35), and he makes little effort to conceal his disdain for traditional First Amendment analysis as a "breeding ground of libertarian sentiment" (p. 34). Fiss aspires to redefine First Amendment jurisprudence to reflect the egalitarian values that for him embody "the maturation of liberalism" (p. 4).

The determination and weight of Fiss's project is most evident in his discussion of R.A.V. v. City of St. Paul. ${ }^{4}$ In that case the Court struck down a St. Paul ordinance that penalized placing

on public or private property a symbol, object, appellation, characterization or graffiti, including, but not limited to, a burning cross or Nazi swastika, which one knows or has reasonable ground to know arouses anger, alarm or resentment in others on the basis of race, color, creed, religion or gender. 5

To prohibit all speech that causes "resentment in others on the basis of race, color, creed, religion or gender" would proscribe a rather large swatch of speech currently protected by the First Amendment. Realizing this, the Minnesota Supreme Court interpreted the ordinance to apply only to "fighting words,"6 but it apparently misconstrued fighting words to mean "expression that 'by its very utterance' causes 'anger, alarm or resentment." "7 The United States

3. See, e.g., Robert Post, Recuperating First Amendment Doctrine, 47 STAN. L. REv. 1249, 1267-70 (1995) [hereinafter Post, Recuperating]; Robert Post, Subsidized Speech, 106 Yale L.J. 151, 188-89 (1996) [hereinafter Post, Subsidized Speech].

4. 505 U.S. 377 (1992).

5. R.A.V., 505 U.S. at 380 (quoting St. PAUL, MINN., LEGIs. COdE $\$ 292.02$ (1990)).

6. In Chaplinsky v. New Hampshire, 315 U.S. 568 (1942), the United States Supreme Court held that "fighting words" were not protected by the First Amendment. It defined fighting words as "those which by their very utterance inflict injury or tend to incite an immediate breach of the peace." Chaplinsky, 315 U.S. at 572. Since Chaplinsky, the Supreme Court has essentially narrowed the category of fighting words to those expressions that constitute a face-to-face incitement to immediate violence. See, e.g., Cohen v. California, 403 U.S. 15, 20 (1971).

7. R.A.V., 505 U.S. at $413-14$ (White, J., concurring in the judgment). 
Supreme Court unanimously held that the ordinance, so interpreted, was unconstitutional under the First Amendment. ${ }^{8}$ But Justice Scalia, joined by four other Justices, authored an opinion for the Court holding that the ordinance would be unconstitutional even if the Minnesota Supreme Court had successfully limited the application of the ordinance to fighting words otherwise unprotected by the First Amendment.

Fiss interprets R.A.V. as a case that turns on the need "to curtail the speech of some to let the less powerful be heard" (p. 111). He attacks Scalia's opinion, as do many others, for its failure to appreciate that the speech "being regulated has a silencing effect" ( $p$. 119), thereby excluding "blacks" and distorting "public debate" (p. 117). But the most revealing moment in Fiss's essay occurs during its discussion of the St. Paul ordinance. Fiss writes: "By its very terms, the St. Paul ordinance seemed to reach very broadly, perhaps too broadly" (p. 113).

I would like to focus on the word "perhaps." Fiss's argument about silencing and subordination applies to the original St. Paul ordinance in exactly the same way as it applies to the ordinance after it was interpreted to reach only "fighting words." Prohibiting all speech causing "resentment in others on the basis of race, color, creed, religion or gender" would also suppress the speech of some in order to let the less powerful be heard. Certainly it would eliminate far more silencing and subordination than would be prevented if the ordinance were to be applied only to fighting words. Why, then, doesn't Fiss apply his same argument to defend the original St. Paul ordinance, the ordinance found unconstitutional by a unanimous Supreme Court? It must be because the egalitarian focus on silencing and subordination is at a certain point trumped by a specifically First Amendment concern for the independent value of speech or the independent rights of speakers.

The word "perhaps" indicates that Fiss knows this to be true, but its terse and grudging acknowledgement also indicates that Fiss cannot bring himself to recognize the point except in a vague, equivocal way. The word gruffly registers the concealed presence of independent First Amendment values, but it brushes them aside without discussion or appraisal. It allows us to glimpse the profound incompatibility between traditional First Amendment values and the insistent egalitarian logic running through Liberalism Divided, and it simultaneously reveals that these values continue to press claims that even Fiss cannot flatly deny.

8. See R.A.V., 505 U.S. at 378. 
II.

It is necessary to keep this moment of manifest incompatibility in mind, for the fundamental thrust of Fiss's perspective is to deny it. The most characteristic rhetorical stance Fiss adopts is to notice a "conflict between liberty and equality" (p. 116), to profess agnosticism as to the outcome of this conflict, and then to attempt to reformulate the question as "a conflict between liberty and liberty" (p. 5).

Fiss attributes to the "liberty" celebrated in the "free speech tradition" an outmoded and naive focus on the protection of individual "autonomy" and "self-actualization" (pp. 12,13). He contrasts this antiquated view of liberty with what he sees as the more satisfactory perspective that "[f]ree speech ... is a public right" (p. 5), whose purpose is "to protect the ability of the people, as a collectivity, to decide their own fate" (p. 38) by ensuring that "public debate is sufficiently rich to permit true collective self-determination" (p. 15). A rich public debate is one in which all can speak, so that we can "hear voices and viewpoints that would otherwise be silenced or muffled" (p. 41).

In this way the value of equality is installed in the heart of a revised account of the First Amendment. The tension between equality and liberty dissolves "once we understand that equality need not be seen as an independent value, based solely on the Fourteenth Amendment, but rather that it has First Amendment dimensions" (p. 87). The potential incompatibility between liberty and equality, which we glimpsed in the word "perhaps," disappears in a flash of theoretical revision.

If we were to spell out the exact terms of this revision, they might look something like this:

(1) The purpose of the First Amendment is to facilitate collective self-determination. ${ }^{9}$

(2) Collective self-determination is a social right theoretically distinct from and unconnected to individual rights of personal autonomy. 10

9. "The First Amendment is a guarantee of collective self-determination ...." P. 101.

10. "The approach I am advocating is not concerned with speaker's autonomy, real or effective, but with the quality of public debate. It is listener-oriented." P. 21. Fiss further observes:

Some liberals see freedom of speech as protecting the individual interest in selfexpression or the right of the individual to say whatever he or she wishes. ... Others understand freedom in more social terms. According to this account, the role of the First Amendment is to preserve the fullness and openness of public debate: to make certain that the people are aware of all the issues before them and the arguments on both sides of these issues. Free speech, in this view, is a public right - an instrument of collective self-determination .....

P. 5. 
(3) Collective self-determination subsists in a rich public debate that fully informs voting citizens of available alternatives and options. ${ }^{11}$

(4) A full and rich public debate requires that all voices be heard, most especially the voices that otherwise would be silenced or muffled. 12

This is an elegant and powerful argument. It provides the theoretical structure for virtually every essay in Liberalism Divided. I suspect that it forcefully captures the political thrust behind a good many important scholarly efforts to refashion First Amendment doctrine according to egalitarian values. It is therefore worth examining with great care.

Like Fiss, I also believe that a primary purpose of the First Amendment is to facilitate collective self-determination, so I shall not have much to say about the first proposition of his argument. I would only note that to attribute to the First Amendment the purpose of facilitating collective self-determination is not necessarily to deny that the First Amendment can also serve other, distinct purposes. There are pockets of First Amendment doctrine that cannot be explained purely by reference to the value of democratic selfgovernance. Examples include issues arising from the regulation of speech between physicians and patients, ${ }^{13}$ of the prices of consumer products, ${ }^{14}$ and of everyday chatter at an airport. ${ }^{15}$

11. Fiss writes:

Under the tradition extolled by Kalven, the freedom of speech guaranteed by the First Amendment amounts to a protection of autonomy. ... However, the theory that animates this protection .... casts the underlying purpose of the First Amendment in social or political terms: The purpose of the First Amendment is not individual selfactualization, but rather the preservation of democracy, and the right of a people, as a people, to decide what kind of life it wishes to live. Autonomy is not protected because of its intrinsic value ... . but rather as a means or instrument of collective selfdetermination. We allow people to speak so others can vote. Speech allows people to vote intelligently and freely, aware of all the options and in possession of all the relevant information.

P. 13.

12. "The state must act as a high-minded parliamentarian, making certain that all viewpoints are fully and fairly heard." P. 101; see also pp. 41, 85-87, 117.

13. See, e.g., Rust v. Sullivan, 500 U.S. 173 (1991); Post, Subsidized Speech, supra note 3, at 175 .

14. See, e.g., Virginia State Bd. of Pharmacy v. Virginia Citizens Consumer Council, Inc., 425 U.S. 748 (1976).

15. See, e.g., Board of Airport Commrs. of Los Angeles v. Jews for Jesus, 482 U.S. 569 (1987). I resist mentioning questions arising from the regulation of wordless music, see Ward v. Rock Against Racism, 491 U.S. 781, 790 (1989), and abstract art, see Hurley v. IrishAmerican Gay, Lesbian and Bisexual Group of Boston, 115 S. Ct. 2338, 2345 (1995). It is difficult to justify protecting these forms of expression on the basis of the kind of cognitivebased model of collective self-determination proposed by Fiss. I believe, however, that protection can be justified by reference to an account of collective self-determination that stresses the sociological infrastructure of public discourse. See Post, Recuperating, supra note 3 , at $1250-60,1276$. Public deliberation requires the prior construction of a "public," and one effect of the arts is to create such a public. 
There is a tendency in Liberalism Divided to jump from the premise that the First Amendment serves the value of collective self-determination to the conclusion that it serves only that value, and that therefore regulations consistent with the value of collective self-determination cannot otherwise be challenged under the First Amendment. But unless these various and (concededly) subsidiary aspects of the First Amendment are to be ruthlessly excised, this conclusion is a non sequitur. So, for example, even if it were true that, as Fiss argues, the content-based suppression of various forms of pornography or racist speech is compatible with collective selfdetermination, it still does not follow that such suppression is automatically consistent with the Constitution, because the suppression might violate other First Amendment values.

This is a complex and conceptually untidy area of analysis. I shall merely flag it, rather than pursue it, because the most likely First Amendment norm that would be violated by the various regulations Fiss seeks to uphold is that of individual autonomy, and Fiss explicitly argues against that norm. His argument is that collective self-determination, rightly understood, is analytically distinct from and incompatible with a norm of individual autonomy. It is to this second proposition in Fiss's argument that I shall turn in the next Part.

\section{III.}

Fiss characterizes the "free speech tradition" (p. 12) as having focused on the "protection of autonomy," in particular on the autonomy of "the speaker" (p. 13). He regards this focus as a profound constitutional mistake. Here is the core of his argument:

Most agree that the underlying purpose of the First Amendment is to protect collective self-determination ... but we are ... divided over the mediating principle that gives fullest expression to that underlying purpose. Here the division is . . . between autonomy and public debate. These two principles represent different ways of understanding and furthering the democratic purposes ....

Those who reduce the First Amendment to a limit on state action tend to regard it as a protection of autonomy. The individual is allowed to say what he or she wishes, free from state interference. ... Even in this account, however, autonomy is not protected as an end in itself, nor as a means of individual self-actualization. Rather, it is seen as a way of furthering the larger political purposes attributed to the First Amendment. It is assumed that the protection of autonomy will produce a debate on issues of public importance that is, to use Justice Brennan's formula, "uninhibited, robust, and wide-open."

The public debate principle, in contrast, acknowledges the problematic character of the instrumental assumption underlying the pro- 
tection of autonomy .... . The purpose of the First Amendment remains what it was under autonomy - to protect the ability of the people, as a collectivity, to decide their own fate. Rich public debate also continues to appear as an essential precondition for the exercise of that sovereign prerogative. But now action is judged by its impact on public debate, viewed as a social state of affairs, rather than by whether it constrains or otherwise interferes with the autonomy of some individual or institution. The concern is not with the frustration of would-be speakers, but with the quality of public discourse. [pp. 36-38]

There are two propositions in this argument that require analytic attention. The first is the claim that individual autonomy is analytically distinct from the value of collective self-determination, so that autonomy should receive protection under a regime of collective self-determination only for the "instrumental" reason that it is expected to produce a richer and fuller public debate. The second is the claim that collective self-determination is essentially about the voting of decisions fully informed by public debate. I shall examine the first proposition in this Part, and I shall discuss the second proposition in Part IV.

Fiss locates the value of collective self-determination in "the ability of the people, as a collectivity, to decide their own fate" (p. 38). This does not seem to me quite right. The value of collective self-determination does not inhere in the people's power to decide their own fate, but rather in their warranted conviction that they are engaged in the process of deciding their own fate. The distinction is crucial, and it lies in the difference between making particular decisions and recognizing particular decisions as one's own. Throughout Liberalism Divided, Fiss displays a tendency toward a reductive decisionism, as if democracy were about the determination of this or that decision, rather than about the underlying authorship of decisions.

We can test this distinction by imagining a situation in which the people in their collective capacity decide issues, but in which individuals within the collectivity feel hopelessly alienated from these decisions. Suppose, for example, that in State $X$ citizens are provided with interactive computer terminals that they are required to use in the morning to register their preferences about various issues. Each morning an agenda for decision (composed by an elected assembly) is presented on the terminal. The citizens of State $X$ must decide what color clothes should be worn; what menu should be served for lunch and dinner; the boundaries of the attendance zones for the neighborhood school; whether a stop sign should be placed at a local intersection; and so on. State $X$ has no public discourse. There are neither newspapers nor broadcast media. The state bans political parties and associations. It proscribes 
public demonstrations and prohibits individuals from publishing their views to other citizens. Each citizen must make up his or her mind in isolation. Decisions in State $X$, however, are made on the basis of the majority vote of the collectivity, and all individuals are henceforth required to comply: to wear blue, or to serve chicken for lunch, or to attend a particular school, or to stop at the local intersection. Individuals in State $X$ feel completely alienated from these decisions. They do not identify with them and instead feel controlled and manipulated by the external force of the collectivity.

Would we deem State $X$ an example of a society that engages in collective self-determination? Although in State $X$ the people retain their ability, "as a collectivity, to decide their own fate," and although they thus meet Fiss's criterion of collective selfdetermination, I very much doubt that we would characterize State $X$ as a democracy. We are much more likely to condemn it as a dystopian tyranny. Rousseau long ago diagnosed the reason for this condemnation: collective decisionmaking is merely oppressive unless there is some internal connection between the particular wills of individual citizens and the general will of the collectivity. ${ }^{16}$

Of course it is implausible to claim, with Rousseau, that there can exist a complete identity between the particular will of the individual citizen and the general will of the democratic state. It is enough that individual citizens can recognize in that general will the potentiality of their own authorship. ${ }^{17}$ When this occurs, collective decisionmaking serves the value of democracy; when individual citizens feel alienated from the general will, collectively voting on issues is merely a mechanism for decisionmaking, a mechanism that can easily turn oppressive.

This argument implies that Fiss cannot analytically sever individual autonomy from collective self-determination. Individual autonomy is not protected by the First Amendment because it is instrumentally necessary for better decisionmaking, but rather because it is intrinsically connected to democratic self-governance. Individual citizens can identify with the creation of a collective will only if they believe that collective decisionmaking is in some way connected to their own individual self-determination. ${ }^{18}$ That is why Jean Piaget was profoundly correct to observe that:

[t] he essence of democracy resides in its attitude toward law as a product of the collective will, and not as something emanating from a

16. See Jean-Jacoues Rousseau, The Soctal Contract 54-56 (Christopher Betts trans., 1994) (1762).

17. For a full explication of this argument, see Robert Post, Meiklejohn's Mistake: Individual Autonomy and the Reform of Public Discourse, 64 U. CoLo. L. Rev. 1109 (1993).

18. For a discussion, see Robert Post, Between Democracy and Community: The Legal Constitution of Social Form, in Democratic CommunIty: Nomos XXXV 163, 178-79 (John W. Chapman \& Ian Shapiro eds., 1993). 
transcendent will or from the authority established by divine right. It is therefore the essence of democracy to replace the unilateral respect of authority by the mutual respect of autonomous wills. ${ }^{19}$

The democratic value of collective self-determination thus entails the value of individual autonomy. In fact, in my view, "[t]he essential problematic of democracy ... lies in the reconciliation of individual and collective autonomy."20 The free speech tradition views public discourse as the arena within which this reconciliation occurs.

It does not follow from this that any of the actual policy prescriptions that Fiss recommends is necessarily wrong or constitutionally inadequate, but it does follow that in assessing their constitutionality one cannot rule out $a$ priori the independent constitutional value of individual autonomy, which is what Fiss attempts to do throughout Liberalism Divided. To compromise individual autonomy is to compromise the foundation of the democratic value of collective self-determination.

IV.

The argument in Part III establishes that Fiss's identification of collective self-determination with collective decisionmaking is inadequate. Fiss believes, however, that the First Amendment value of public debate stems entirely from its instrumental role in facilitating informed and accurate decisions. Fiss argues that the Constitution protects the quality of public debate because an informed public dialogue is necessary to supply "the electorate with the information it needs to make free and intelligent choices about government policy, the structure of government, or the nature of society" (p. 40).

We do of course have a constitutional interest in maximizing the quality of our public debate, so that our collective decisions can be as informed and as accurate as possible. This constitutional interest, however, is most precisely addressed by First Amendment protection for the "marketplace of ideas in which truth will ultimately prevail."21 But our constitutional interest in collective self-determination is different, for even if collective decisionmaking is fully informed and accurate it may still fail to achieve the value of democratic self-governance.

Imagine, for example, that even though there is no public discourse in State $\mathrm{X}$, the State nevertheless provides its citizens with all information material to the issues on the day's agenda, meaning

19. Jean Piaget, The Moral Judgment of the Child 362-63 (Marjorie Gabain trans., 1965) (emphasis added).

20. Robert Post, Constitutional Domains: Democracy, Community, ManageMENT 7 (1995).

21. Red Lion Broadcasting Co. v. FCC, 395 U.S. 367, 390 (1969). 
all information that its citizens feel would be pertinent to their informed decisionmaking. Assume that public debate could add nothing to the quality or extent of the information provided. So long as the citizens of State $X$ continue to feel alienated and oppressed by their exercise of collective decisionmaking, I very much doubt that providing complete information would alter our conclusion that State $\mathrm{X}$ should be regarded as undemocratic. Democratic values are not realized unless there is a linkage of individual and collective autonomy, even if collective decisionmaking is fully informed.

The nature of that linkage will of course vary from culture to culture and from time to time. The image that emerges from Liberalism Divided is that of a democratic citizen who participates in collective decisionmaking merely through listening and voting intelligently, rather than through speaking or debating. "[T]he approach I am advocating," Fiss writes, "is not concerned with the speaker's autonomy, real or effective, but with the quality of public debate" (p. 21). Fiss therefore considers as primary "the informational needs of the public" (p. 6). "We allow people to speak," says Fiss, "so others can vote" (p. 13). But Fiss thereby offers a strikingly passive image of the democratic citizen, who can be brought to identify with collective self-determination merely by being provided with the authority to vote based upon full and accurate information.

Although Fiss is aware that " $[\mathrm{t}] \mathrm{o}$ be a consumer, even a sovereign one, is not to be a citizen" (p. 40), his image of the democratic citizen oddly reproduces the structural position of the consumer. Like Fiss's voters, consumers can exercise ultimate decisionmaking power; they can determine whether or not to buy a product. And, like Fiss's voters, consumers can exercise this power on the basis of more or less complete information. What is missing from Fiss's account of democratic citizens, and what ultimately distinguishes democratic citizens from both voters and consumers, is the concept of active participation. ${ }^{22}$ Democratic citizens participate in setting the agenda and framing the terms of the very issues that they are, as voters, called upon to decide.

Participation is at the core of the "free-speech tradition" that Liberalism Divided repudiates. The tradition renders the American citizen as active, as engaged in "free debate and free exchange of ideas." 23 The tradition does not defend speakers' rights merely be-

22. On the concept of active participation, see, for example, Alexis DE Tocouevilie, DemOCRACY IN AMERICA 509-524 (J.P. Mayer ed. \& George Lawrence trans., 1969) (1831),

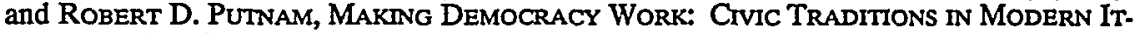
ALY 87-88 (1993).

23. Terminiello v. Chicago, 337 U.S. 1, 4 (1949). 
cause they produce better informed decisions. Instead it claims that "[t]he right to speak freely and to promote diversity of ideas and programs is ... one of the chief distinctions that sets us apart from totalitarian regimes." 24 The rights of speakers are protected primarily because they create the opportunity for democratic citizens to come to identify with the collective will through their own potential active participation. ${ }^{25}$ That participation extends to the creation of a national culture and identity, which will ultimately find expression through legislation. The opportunity to engage public and social life in this way is what differentiates us from "totalitarian regimes." Public discourse is thus conceptualized as the medium through which citizens can come to reconcile individual and collective autonomy. This is the fundamental reason why the free speech tradition protects both speakers' rights and the free public debate required by speakers' rights.

There are moments in Liberalism Divided when Fiss seems to dismiss this conceptualization as quaint and outmoded, appropriate for "a world that no longer exists and that is beyond our capacity to recall" (p. 29), a "world of the street corner speaker" (p. 16). Fiss seems to regard this notion of the citizen as ill-suited for the bleak landscape of contemporary America, with its overpowering corporations, media moguls, and gaping class divisions. Fiss makes many important points about the perverse ways that First Amendment doctrine actually plays out in contemporary America, points well worth careful consideration. But nothing that he says supports the conclusion that underpins his constitutional analysis, which is that American citizenship has become so passive and so etiolated that citizens can be brought to identify with collective decisionmaking merely because they can vote on the basis of full and accurate information. ${ }^{26}$

24. Terminiello, 337 U.S. at 4. "[T] $]$ he First Amendment serves to ensure that the individual citizen can effectively participate in and contribute to our republican system of selfgovernment." Globe Newspaper Co. v. Superior Court of Norfolk, 457 U.S. 596, 604 (1982) (citing Thornhill v. Alabama, 310 U.S. 88, 95 (1940)).

25. Of course speakers' rights do not guarantee that collective decisionmaking will fulfill democratic values. But we can say that without speakers' rights democratic values will not be fulfilled, particularly under the conditions of heterogeneity characteristic of the modern state. Speakers' rights are thus a necessary but not sufficient condition for the realization of democratic values.

26. This point seems to me adequate to meet the arguments of the most articulate and careful defense of Fiss's position, which may be found in Morris Lipson, Autonomy and Democracy, 104 YALE L.J. 2249 (1995). Fiss specifically invokes Lipson. See p. 110. Although Lipson concedes the internal connection between individual autonomy and collective selfdetermination, see Lipson, supra, at 2254 , he conceptualizes individual autonomy entirely in terms of informed decisionmaking. Thus he writes that "[v]oter autonomy, the autonomy that is at stake in true collective self-determination, and hence which must be the focus of collectivism, is hearer autonomy." Id. at 2265. Lipson does not consider the possibility that the mere autonomy of the voter may fail to provide a sufficient connection between individual and collective self-determination. 
I do not mean to deny, of course, that voting is an important means of participation in a democratic polity. I only claim that voting is not by itself sufficient to realize the value of democratic selfgovernance. Other forms of participation must also be protected. Citizens must be able to associate, to organize, to speak, to march, to petition, and so forth. It follows that Fiss cannot excise speaker autonomy as an important dimension of First Amendment analysis. His various policy prescriptions must therefore be assessed, at least in part, in terms of their effect on speakers' rights.

\section{V.}

The fourth and concluding proposition in Fiss's argument is that a full and rich public debate requires that all voices be heard, most especially voices that would otherwise be marginalized. Fiss believes that the First Amendment obliges the state to act affirmatively "as a high-minded parliamentarian, making certain that all viewpoints are fully and fairly heard" (p. 101). Fiss argues that public debate can serve its function of fully informing voters only if it includes all potential perspectives. He contends that "supplying the electorate with the information it needs to make free and intelligent choices" requires the state to "put on the agenda issues that are systematically ignored and slighted," so that the democratic polity can "hear voices and viewpoints that would otherwise be silenced or muffled" (pp. 40-41). I shall argue in this Part that Fiss's arguments are confused, because they confound issues of quality with those of equality.

The instability of Fiss's position is displayed in an important metaphor that Fiss employs in his discussion of government subsidies. Fiss writes that the state must set the agenda of public discourse by making decisions that "are analogous to the judgments made by the great teachers of the universities of this nation every day of the week as they structure discussion in their classes" ( $\mathrm{p}$. 103). The comparison is apt: Great teachers do in fact seek to inform their students so that the latter can exercise their own independent judgment. But great teachers do not accomplish this task by exposing their students to all potential points of view.

To fully parse Fiss's arguments, therefore, one must distinguish between two metaphors that Fiss employs to characterize the ideal state. On the one hand, Fiss describes the state as a teacher which informs and educates its citizenry; on the other hand, he describes the state as a parliamentarian which fully and fairly moderates a national town meeting, allowing all viewpoints to be heard. Fiss does not perceive any tension between these two metaphors, but in fact they are quite distinct. While a parliamentarian state would 
indeed attempt to extend the opportunity to be heard to all potential perspectives, a pedagogical state would not.

Teachers educate their students by introducing them primarily to helpful and informative perspectives. Professors of astronomy do not study the origins of the universe by ensuring that "all viewpoints are fully and fairly heard" or by emphasizing "voices and viewpoints that would otherwise be silenced or muffled." They do not expose students to every historical myth, discarded hypothesis, religious fable, or crackpot explanation, however much these various theories may be muffled or silenced within the academic community. Great teachers do not overwhelm and confuse their students by showering them with indiscriminate information.

A state charged with the responsibility of establishing the richest and most informative public debate would not act any differently. It would expose its electorate to the most useful and pertinent perspectives. A pedagogical state would not inundate its electorate with indiscriminate information that would render public debate confusing and overwhelming. Consider, for example, a public dialogue about reform of the welfare system. Can it seriously be contended that such a dialogue would necessarily be improved if the state were to ensure that all otherwise marginalized voices were to be amplified and broadcast? Would the quality of public discussion be improved if the state were to provide a platform for every racist, eugenicist, or fascist? For every harebrained and self-appointed expert? For every ugly and irresponsible opinion? There may be reasons for requiring the state to take such action, but surely these reasons do not include improving the intrinsic quality of public debate.

If this analysis is correct, Fiss's claim that collective selfdetermination requires a rich and informative public debate does not lead to the conclusion that the state should ensure that "all viewpoints are fully and fairly heard." Insofar as the logic of Fiss's First Amendment argument turns on this claim, therefore, Fiss must advance a vision of the state as a teacher rather than as a "highminded parliamentarian."27

27. If the state's role as teacher is accepted, it can be used to defend several of Fiss's particular policy prescriptions. So, for example, if Fiss's empirical premises about silencing are granted, it would not be difficult for Fiss to argue that the speech "silenced" by pornography or hate speech is valuable and informative and that such speech therefore ought to be protected so as to improve the quality of public debate. Most teachers would make a similar judgment in their own classrooms.

Other of Fiss's policy proposals, however, are not so easily rehabilitated. So, for example, Fiss argues in his discussion of public subsidies that the state ought not to act in a way that reinforces "prevailing orthodoxies." P. 107. The state instead ought to ensure that "all viewpoints are fully and fairly heard," so that "public debate is as rich and varied as possible." $P$. 101. This prescription casts the state as a parliamentarian, rather than as a teacher, and I do not think it can be defended by reference to the latter role. The prescription can only be defended if the role of parliamentarian can be defended. 
VI.

The image of the parliamentarian state, however, resonates throughout Liberalism Divided much more insistently than does that of the pedagogical state (pp. 84-85, 101, 117-18, 153). Although the ideal of the parliamentarian state is in tension with the goal of a rich and informative public debate, Fiss seems intensely committed to it. Evidently it expresses egalitarian values that Fiss wishes to infuse into First Amendment jurisprudence, regardless of the quality of public debate.

The more one presses the metaphor of the parliamentarian state, however, the more difficult it becomes to ascertain exactly which egalitarian values the image is meant to represent and exactly how these values are meant to embody the ideal of collective selfdetermination. Roughly speaking, there are two distinct kinds of egalitarian values that the image could express. The parliamentarian state could stand for an equality of ideas, or it could stand for an equality of persons. I shall examine the first of these possibilities in this Part; I shall examine the second in Part VII.

At times, the argument in Liberalism Divided that the parliamentarian state should ensure that "all viewpoints are fully and fairly heard" appears to rest on the premise that all ideas are equal, and hence that the state should be obliged to treat all ideas equally. This premise has far-reaching implications that can perhaps best be grasped by contrasting it with contemporary First Amendment jurisprudence.

That jurisprudence itself contains standards of equality. Although it prohibits the state from regulating public discourse in a way that discriminates among ideas, it does not regard ideas as intrinsically equal. Instead the First Amendment tradition prohibits content discrimination because it imposes upon the state the obligation to treat all participants in public discourse equally, even if the state believes that the ideas of some are more (or less) worthy of public attention and dissemination. ${ }^{28}$ This obligation derives from the principle that the self-determining agency of all persons should be regarded with equal respect. The Court has interpreted this principle to mean that "the concept that government may restrict the speech of some elements of our society in order to enhance the relative voice of others" should be repudiated as "wholly foreign to the First Amendment."29 The Court has viewed repressing the speech of some in order to augment the speech of others as equivalent to valuing the self-determination of some more highly

28. See Robert C. Post, Racist Speech, Democracy, and the First Amendment, 32 WM. \& MARy L. Rev. 267, 290-91 (1991) [hereinafter Post, Racist Speech]; Post, Subsidized Speech, supra note 3 , at $188-89$.

29. Buckley v. Valeo, 424 U.S. 1, $48-49$ (1976). 
than that of others, and hence as treating the self-determining agency of citizens as unequal before the law.

We know, however, that Fiss rejects this particular concept of equality. Time and again Fiss states in Liberalism Divided that "we may sometimes find it necessary to 'restrict the speech of some elements of our society in order to enhance the relative voice of others,' and ... unless the Court allows, and sometimes even requires, the state to do so, we as a people will never truly be free" (p. 30). Appealing to an image of the state as parliamentarian, Fiss makes this same point about the regulation of pornography (pp. 8485), hate speech (pp. 117-18), and public access to the media (p. 38).

By interpreting the First Amendment to recognize an equality of ideas, instead of an equality of persons, Fiss would enable the state to discriminate constitutionally among persons. The state could treat persons differently, so long as it did so in order to equalize the treatment of viewpoints. Reading Liberalism Divided as asserting an equality of ideas also would be compatible with Fiss's determination to deny speakers' rights and to focus on the nature of public debate.

The difficulty with this approach, however, is that it is highly implausible to contend that ideas, qua ideas, must be accorded equal respect. We do not in practice treat ideas with equal respect. To think is to distinguish between good and bad ideas, between useful and useless ideas, and so on. One who cannot discriminate among ideas cannot properly be said to think at all. Nor is discriminating among ideas regarded as something shameful. We do not believe that we should treat ideas with equal respect. There is no theoretical reason to attribute inherent dignity to ideas as we do to individuals. We use ideas to forge a culture. Hence ideas of genocidal torture do not intrinsically deserve respect; we may properly express our revulsion. For these reasons it would be quite incorrect for Fiss to claim, as did Meiklejohn before him, that there is an "equality of status in the field of ideas." 30

Perhaps, then, Fiss wishes to defend a less radical proposition. We might interpret the image of the parliamentarian state to stand for the proposition that the state should be required to treat ideas as if they were equal, even if they are not in fact equal. The difficulty, however, is in justifying this proposition. If the state's obligation to treat ideas as if they were equal derives from the equal respect that the state owes to speakers as participants in the process of democratic self-governance, then Fiss must embrace the kind of

30. Alexander Meiklejohn, Polmitcal Freedom: The Constitutional Powers of THE PEOPLE 27 (1948). I would also note that because there are always an infinite number of potential ideas, it is in any event conceptually unclear what it could possibly mean to require that "all viewpoints" be "fully and fairly heard." 
equality of persons already embodied in the free speech tradition, a form of equality Fiss is determined to deny. But if the state's obligation derives from the government's incompetence to discriminate between good and bad ideas, the state would be disabled from acting as a teacher to enrich public debate, a role upon which Fiss wishes to insist. 31

It is possible that Fiss means to use the image of the parliamentarian state not to represent a strict equality of ideas, qua ideas, but rather to express the state's obligation to redress inequalities that occur among ideas because of social imbalances of power and influence. If one carefully examines the contexts in which Fiss invokes the image of the parliamentarian state, one finds that they characteristically involve groups that are socially disadvantaged. Fiss wishes to repress pornography because it "has the effect of interfering with the speech rights" of women (p. 84). He wishes to prohibit hate speech because it "discourages" African Americans "from participating in the deliberative activities of society" (p. 117). He wishes to regulate the media so that "the speech" of the rich and powerful will not "drown[] out the voices" of those without equivalent resources (p. 38). He wishes to prohibit government subsidies from being "used to reinforce prevailing orthodoxies," most particularly by excluding "the gay community" (pp. 107, 102).

What seems to drive Fiss, then, is not the ambition to make ideas equal, but rather to rectify distortions of public debate that reflect gross differences in social and financial power. This may be what Fiss means when he refers to the state's obligation to afford all viewpoints the opportunity to be "fully and fairly heard." We can interpret Fiss as advocating that public discourse would be better and richer if it were fairly to represent the ideas of socially oppressed groups, ideas that would otherwise be marginalized.

Fiss does indeed advance claims regarding such distortions. Some of these claims are more convincing than others. So, for example, the chapters in Liberalism Divided that address groups traditionally protected by the Equal Protection Clause are not persuasive. This is because Fiss's line of argument requires him to establish that the silencing effects of pornography and hate speech produce systemic distortions in public discourse. Fiss contends that the First Amendment does not guarantee any particular person the right to speak; it only guarantees that "everything worth saying is said" (p. 26). Others have called for the regulation of hate speech and pornography because it silences particular individuals through

31. See p. 26 ("I believe in reason and in the deliberate and incremental methods of the law: The courts are no more disabled from giving content to the enrichment of the public debate idea than to any other...."). 
forms of what has been called "illocutionary disablement."32 But Fiss must establish something different, which is that hate speech and pornography systematically repress the expression of viewpoints within a national dialogue on race and gender. Even a modest review of the national media or academic publications renders this proposition quite implausible, and Fiss certainly makes no effort empirically to justify his case.

The strongest and most deservedly influential chapters in Liberalism Divided, on the other hand, call our attention to inequalities that do not involve groups traditionally safeguarded by the Equal Protection Clause. They instead discuss the systemic distortions in public discourse caused by "the skew of the market" (p. 43), and in particular by the commercial interests of large media outlets. Fiss seems clearly right to identify these distortions as a major issue of social concern. He presents a forceful and instructive indictment of the disparity between the structure of communication that is naturally generated by the market and the structure of communication that would be required by a rich and informative public discourse.

But even if the fact and adverse consequences of this disparity are accepted, the amelioration of this condition would not justify an appeal to the parliamentarian state, which reproduces all viewpoints mechanically. It instead would justify a call for a pedagogical state that would repair distortions of public debate adversely affecting its quality and depth. A pedagogical state might well function independently of the market to regulate speech so as to educate its citizens about all serious and reasonable points of view in the society around them.

A pedagogical state, however, would not amplify and broadcast worthless and undeserving ideas. Ideas are no less worthless and undeserving because they come from financially and socially marginalized persons. If Fiss is willing to count the exclusion of undeserving ideas as a "distortion" of public discourse, then he must be appealing to egalitarian values that are quite distinct from any concern with the quality and richness of public debate. ${ }^{33}$ If my argument in this Part is correct, these values also cannot plausibly

32. Rae Langton, Speech Acts and Unspeakable Acts, 22 PHIL \& PuB. Afr. 187, 293, 315 (1993); see also Jennifer Homsby, Illocution and Its Significance, in FOUNDATIONS OF SPEECH ACT THEORY 198-200 (Savas L. Tsohatzidis ed., 1994); Richard Delgado, Words That Wound: A Tort Action for Racial Insults, Epithets and Name-Calling, 17 HARV. C.R.-C.L. L. REv. 133 (1982); Charles R. Lawrence III, If He Hollers Let Him Go: Regulating Racist Speech on Campus, 1990 Duke L.J. 431.

33. An alternative interpretation of the image of the parliamentarian state is that it expresses a rigorous notion of hearer autonomy. This notion is developed in the work of Morris Lipson, supra note 26. On this reading of Fiss, the goal of the parliamentarian state is to ensure that all "relevant" viewpoints are disseminated, meaning all viewpoints that would, from the perspective of any citizen, make a difference to his or her decisionmaking. See id. at 2264. The parliamentarian state thus simply would respond to the felt needs of its citizens. It would neither treat all ideas as equal nor assume that ideas should be treated as if they were 
refer to a postulated equality of ideas. Perhaps, then, they refer to an equality of persons.

\section{VII.}

I should note at the outset that it is difficult to read Liberalism Divided as asserting an equality of persons, because so many of the book's prescriptions entail treating persons unequally. To unfold rigorously the implications of an equality of persons, therefore, will no doubt yield numerous inconsistencies with many of the book's positions. Nevertheless, there are moments in Liberalism Divided when Fiss seems to rely upon a postulated equality of persons, and it may be that the image of the parliamentarian state is the covert avenue through which this equality implicitly is expressed.

At times, Fiss writes as though he believed that all persons were entitled to equal influence on public debate. This form of equality is distinct from that embodied in the free-speech tradition, which presently requires that the state treat equally the self-determining agency of all persons. Fiss seems instead to appeal to the very different notion that the state be required affirmatively to ensure that all persons exercise equal influence on public discourse.

One can see traces of this perspective in Fiss's analysis of the "sociological" silencing effects of pornography. Following MacKinnon, Fiss argues that pornography "leads men not to listen to what women say or not take them seriously; and it is this social practice that impoverishes public debate" (pp. 85-86). Fiss concludes that in such circumstances restricting pornography does not cast the state "as a censor, but rather as a parliamentarian, requiring some to shut up so others can speak" (pp. 84-85).

These passages demonstrate the way in which Fiss characteristically intertwines the image of the state as a parliamentarian (allowing all to speak) with the image of the state as a teacher (saving public debate from impoverishment). But these two images must be sharply distinguished. One can see the difference clearly in the

\footnotetext{
equal, nor would it make any judgment at all about whether ideas were worthless or undeserving.

Purely on textual grounds, this account of the parliamentarian state seems implausible as an interpretation of Fiss. It explicitly equates voters with consumers of information, and it therefore deprives the state of any criteria for the independent assessment of the richness or quality of public debate. Moreover, Fiss never associates the invocation of the parliamentarian state with a focused discussion of the autonomy needs of an audience; he instead almost invariably centers his attention on the uneven suppression of particular points of view. Most importantly, however, this account of the parliamentarian state will, in the end, render it indistinguishable from the pedagogical state. This is because the state could never really know what information would in fact be "relevant" to its citizens, and it thus would be forced to disseminate information deemed relevant to the decisions of "reasonable" citizens (or some such equivalent). Since the construction of "reasonableness" is ineluctably normative, the state would in practice be forced to assume the role of a teacher. It would not actually disseminate viewpoints it deemed worthless or undeserving.
} 
role of the literary critic. One function of the critic is to diminish the influence of bad novelists and to increase the influence of good novelists. The critic thus fills the role of teacher, not parliamentarian; she increases the quality of public discourse, but she does so precisely by depriving some speakers of influence.

Fiss's commitment to the parliamentarian state can therefore be taken to mean that he believes that women ought to have the right to be taken "seriously" regardless of whether doing so will improve public debate. But if we formulate the matter this way, we must ask whether the proposed right also includes bad novelists. Do we believe that bad novelists have a First Amendment right to exercise the same influence on public discourse as do good novelists, so that the parliamentarian state ought to be called upon to restrict negative critique?

Merely to frame this question is to see that influence is in some measure a result of the assessment of ideas, and that for this reason efforts to equalize influence must involve both the equalization of ideas and the control of intimate and independent processes by which individuals evaluate ideas. Such efforts are intrinsically undesirable when performed by the state, both because ideas are not equal and because any such governmental efforts likely would verge on the tyrannical. ${ }^{34}$

Perhaps, then, we can read Liberalism Divided as expressing a distinct and milder view of the equality of persons. Although everyone cannot and should not exercise equal influence on public debate, Fiss sometimes writes as if everyone ought to have an equal opportunity to do so. So, for example, Fiss asserts that "[d]emocracy requires that everyone have an equal chance to speak and to be heard." 35 The opportunity to speak and to be heard underlies Fiss's defense of the St. Paul ordinance at issue in R.A.V. v. City of St. Paul.36 Fiss argues that in banning hate speech "[t]he city is acting as a parliamentarian trying to end a pattern of behavior that tends to silence one group and thus distorts or skews public debate" (p. 117). The notion of a "distortion" of public debate, however, only makes sense against a baseline. Fiss appears to use the image of the parliamentarian state to identify a baseline in which everyone is given a fair chance to speak and to influence pub-

34. See Ronald Dworknn, Freedom's LaW: THE Moral Reading of the American CONSTITUTION 27-28 (1996).

35. P. 85. The sentence quoted in text seems to me violently inconsistent with the proposition that Fiss reiterates throughout Liberalism Divided that the First Amendment requires not that everyone have a chance to speak, but that everything worth saying be said. This is an example of how a postulated equality of persons will necessarily lead to inconsistencies with various policy prescriptions otherwise advanced in Liberalism Divided.

36. 505 U.S. 377 (1992). 
lic debate. ${ }^{37}$ Public debate is "distorted" if some persons are given a greater opportunity than others to affect public discourse.

Persons can be denied the opportunity to exercise influence on public debate in a great many different ways. Some ways are perfectly acceptable, whereas other ways are uncontroversially illegal. An example of the first occurs whenever the review of a scathingly effective literary critic denies a young novelist all hope of further publication. An example of the second occurs whenever a person is denied the opportunity to affect public discourse because of blackmail, extortion, or the threat of force. There are, therefore, constitutionally legitimate and illegitimate ways in which the opportunity to exercise influence on public debate can be denied. ${ }^{38}$

To postulate that persons have the right of equal opportunity to influence public debate, however, is to operate at a level of abstraction that transcends these differences. Fiss never makes an extended effort to establish the legitimacy or illegitimacy of particular methods of denying access to influence. He seems interested instead in expressing a general right of equal access to influence. One might imagine this right as embodied in a proposal (which Fiss does not make) that all citizens receive equal access to media time - say five minutes per person. Under such a proposal, every citizen

37. If Fiss had meant to refer to a baseline of a rich and informative public debate, then he would in the passage have referred to the pedagogical state, rather than to the parliamentarian state. In its role as parliamentarian, however, the state must "refrain from choosing among viewpoints"; it instead must make "certain that all viewpoints are fully and fairly heard." P. 101. Fiss appears to justify the St. Paul ordinance on these general grounds of fairness, rather than on the ground that the particular views silenced by hate speech are especially valuable or necessary to public debate. Alternatively, of course, Fiss may have intended to refer to the baseline of a public debate in which all potential viewpoints are equally presented. But, as we have seen, the postulated equality of ideas that supports this view is quite implausible.

38. Fiss seems to recognize this point when he attempts to distinguish between two ways in which women are "silenced" by pornography. The first is "ideational," and it occurs when silencing is caused "solely from the content of" pomography. P. 85. The second is "sociological," and it is caused by "the industrial dimensions of pornography." Id. Fiss believes that ideational silencing ought not to be a ground for restricting pornography, because it would give the state "the power to determine which ideas should enter or become part of public debate, a power that is inconsistent with the value entrusted to the First Amendment popular sovereignty." Id. But he does believe that pornography can be restricted because it causes sociological silencing.

I believe that Fiss's distinction is unworkable, because the influence of all ideas occurs within the context of social circumstances. These circumstances include the status of a speaker, existing social prejudices, and so forth. For this reason, efforts to evaluate the "ideational" force of an idea characteristically take the form of exposing and discounting the social circumstances that affect the reception of the idea. See Post, Racist Speech, supra note 28, at 306-07. These efforts can never be fully successful, however, for attempts to distinguish the pure cognitive force of an idea from the social setting in which the idea is advanced will themselves be influenced by social circumstances. The distinction that Fiss wishes to draw can thus only be made from a perspective that is itself impervious to social circumstances. Because we typically do not have access to such a perspective (at least for claims other than those of instrumental reason), Fiss's distinction ultimately amounts to a license to discriminate between speakers. 
would have an exactly equal chance as every other to influence public debate. Speech, like the right to vote, would be parceled out to citizens in exactly equal terms.

Notice how starkly this proposal reveals the tension between the goal of improving the quality of public debate and the goal of ensuring that "everyone have an equal chance to speak and to be heard" (p. 87). Nothing could possibly be less rich or less informative than television programming devoted to giving each citizen exactly the same amount of time to speak about the subject of his or her choice. Yet if one interprets the image of the state "as a highminded parliamentarian, making certain that all viewpoints are fully and fairly heard" (p. 101) as requiring all citizens to have an equal opportunity to influence public debate, this dismal result seems inevitable. ${ }^{39}$

The point I wish to explore, however, is the relationship between a general right of equal opportunity to influence public debate and the fundamental First Amendment value of collective self-determination. Allotting speech in precisely equal portions entails severing speech from intensity. Those who care more will not be able to speak more. It also entails severing speech from knowledge. Those who know more will not be able to speak more. In fact, allotting speech in precisely equal portions detaches expression from all the motivating circumstances that in actual life underlie the impulse to speak.

We might accept this detachment in limited and formal circumstances, as for example at town meetings or legislative assemblies, where necessity demands that formal rules of equal opportunity prevail. ${ }^{40}$ But to conceptualize the whole of expression as detached in this way from the sources of action is a sure recipe for alienation. Fitting expression to the Procrustean bed of equality would separate speech from the social contexts that impel participation, and in this way cut the connection between expression and the springs of individual engagement. In such a system, public discourse could no longer mediate between individual and collective selfdetermination. To read the Constitution as requiring the state to ensure that all citizens have an equal chance to influence public de-

39. It is possible, however, that Fiss means the concept of an "equal chance" to be interpreted in a purely aleatory sense, so that his goal would be satisfied by a lottery, offering to each citizen an exactly equal chance of receiving a given allotment of media time to speak about the issues of their choice. But this interpretation would seem to have nothing particular to recommend it, and it would be subject to the same objections (which are discussed in text) as would the concept of "equal opportunity."

40. On the use of instrumental reason that must ground this concept of "necessity," see Post, supra note 17. 
bate, therefore, would contradict the basic First Amendment value of collective self-determination. ${ }^{41}$

\section{VIII.}

Despite Fiss's best efforts, it seems difficult to bring "equality" within the First Amendment, except insofar as equality is meant to refer to the self-determining agency of democratic citizens. Approaches that attempt to maximize other kinds of equality of ideas or of persons are either implausible or inconsistent with the principle of collective self-governance. The ideal of the parliamentarian state, which is a leitmotif of Liberalism Divided, seems therefore to represent a form of equality quite at odds with the intrinsic goals of the First Amendment. It reflects a true tension between equality and liberty; it does not, as Fiss had hoped to demonstrate, express an internal conflict within liberty.

What are we to make, then, of Fiss's powerful indictments of the inequalities that afflict our contemporary media, of his clear-sighted perception of the many ways in which the quality of our public discourse is undercut by the skew of market forces? One possible answer is to embrace the alternative image Fiss proposes, that of the pedagogical state. I have elsewhere argued that this image of the state is incompatible with democratic self-governance, 42 and I will not repeat those arguments here. Suffice it to say that citizens engaged in collective self-determination through participation in public discourse are not students to be taught, but autonomous masters of their fate. They are adults, not pupils.

To cast the state as a teacher is to permit the state to define the agenda and parameters of public debate; it is to presuppose an Archimedean point that stands outside of the processes of selfdetermination. This would be true even if the ambition of the pedagogical state were merely to present "fully and fairly" all views on public matters that the state regarded as plausible and socially relevant. Although Fiss speaks as though the agenda of public discourse is a natural phenomenon that evolves "organically" without public intervention (p. 118), in fact, as one noted social scientist has succinctly observed, "Just what is a political issue is itself a political

41. The argument that citizens possess a general right of equal access to influence public debate thus should be fundamentally distinguished from the argument that citizens should have sufficient access to public debate so as to ensure that public debate serves for them the function of reconciling individual and collective autonomy. The latter argument is not only consistent with, it is actually entailed by, the free speech tradition. See id. at 1133-36. It is an argument that tums on the nature of liberty, however, and not on the egalitarian values represented by the metaphor of the parliamentarian state.

42. See id. There is of course an appropriate role for the state as teacher; the project of public education rests on such a role. The state as educator, however, creates structures of managerial supervision, rather than democratic self-governance. See, e.g., Post, Subsidized Speech, supra note 3, at 165-67; Post, Racist Speech, supra note 28, at 317-25. 
issue."43 For this reason the image of the pedagogical state is in actuality profoundly anti-democratic. To make the state the final arbiter of the quality and agenda of public discourse would in the end give to the state "the power to determine which ideas should enter or become part of public debate," a power that Fiss himself acknowledges "is inconsistent with the value entrusted to the First Amendment - popular sovereignty" (p. 85).

Must we then simply accept the inadequacies of our present disgraceful structure of communication? Are there no remedies consistent with the free speech tradition? I would argue to the contrary. The First Amendment value of collective selfdetermination is itself predominant only within the limited arena of public discourse, and much regulation outside of that arena is therefore constitutionally unproblematic. ${ }^{44}$ The boundaries of that arena are negotiable. So, for example, I have described elsewhere how corporate domination of media outlets might perhaps be addressed by characterizing certain broadcast media as public functionaries and hence as subject to various forms of regulation that would otherwise be prohibited by the free speech tradition. ${ }^{45}$ Even within the realm of public discourse itself, however, the free speech tradition recognizes certain justifications for restrictions on speech. In other work I have tried to sketch what these justifications might look like in the context of campaign finance reform. ${ }^{46}$ Certainly it is compatible with the free speech tradition for the state to act positively to subsidize and thereby to supplement and improve public discourse. .7 All of these methods would help to ameliorate the ills so effectively diagnosed by Fiss.

None of those approaches, however, would deny the principle of speaker autonomy; none would deny the concept of individual rights; none would set up the state as the pedagogical arbiter of public discourse; none would impose the egalitarian norms implicit in the image of the parliamentarian state. Each would respect public discourse as a medium for the reconciliation of individual and collective autonomy.

Why, then, does Fiss ignore them in favor of a wholesale repudiation of the free-speech tradition? I suspect that it is because Fiss sees in the free speech tradition a conception of the state that he 1993).

43. William H. Riker, Introduction to AgENDA Formation 1, 3 (William H. Riker ed.,

44. See Post, Recuperating, supra note 3.

45. For a discussion as to the nature of such an argument, see Post, supra note 17, at 112528; Post, Subsidized Speech, supra note 3, at 158-63.

46. See Post, supra note 17. For a discussion of what remedies for hate speech might look like in the context of the free-speech tradition, see Post, Racist Speech, supra note 28.

47. On the authority of the state to supplement public debate, see Post, Subsidized Speech, supra note 3, at 176-94. 
wishes to attack. Fiss is frank to say that he has been inspired by "our historical experience with the activist state in the sixties" (p. 43). During the 1960s, the state, most particularly exemplified in the "independence" of its judicial branch (p. 44), stood over and against the social prejudices of society and the economic inequities of the market (p. 4). Because society and majoritarian processes could not be trusted, the judiciary functioned as an independent source of constitutional value. Fiss wants to bring this same perspective to bear on First Amendment jurisprudence. Liberalism Divided candidly appeals to the history of judicial heroism exemplified by the 1960s (pp. 43-44).

When that heroism is applied to the process of collective selfdetermination, however, it comes into tension with the most basic assumption of the free speech tradition. That assumption is captured concisely in New York Times Co. v. Sullivan when it cites Madison's observation that "[ $t]$ he people, not the government, possess the absolute sovereignty."48 Democratic self-governance is the core of the free speech tradition. The remark of New York Times that public debate should be "uninhibited, robust, and wide-open," which Fiss is fond of quoting, is merely a derivative proposition. ${ }^{49}$

The free speech tradition can, of course, envision the state, as Fiss wishes to present it, "possibly as a friend of freedom" (p. 5). It can empower the state to embody and to advance important social values, including egalitarian values, as it did during the 1960s; it can even encourage the state to enrich public discourse itself. ${ }^{50}$ But what the free speech tradition cannot permit is the elevation of the state into a source of national values capable of improperly censoring public discourse itself, 51 for this would be to anticipate and to contradict the very process of democratic self-governance.

Fiss reads these self-imposed limitations as mere "libertarian sentiment" (p. 34). He therefore proposes a form of free speech jurisprudence in which the state is empowered to regulate public discourse, either as a teacher or as a parliamentarian enforcing egalitarian norms. But by so doing Fiss necessarily puts the state in the position of dictating to the people the outcome of their public deliberations.

I agree with Fiss that the battles of the 1960s were a magnificent vindication of our constitutional tradition. But I fear that

48. New York Times Co. v. Sullivan, 376 U.S. 254, 274 (1964).

49. New York Times, 376 U.S. at 270; see p. 13 (quoting same).

50. See Post, Subsidized Speech, supra note 3, at 176-94.

51. I add the word "improperly," because in certain circumstances the free speech tradition itself would allow for, and perhaps even require, restrictions on public discourse. See, e.g., Robert C. Post, The Constitutional Concept of Public Discourse: Outrageous Opinion, Democratic Deliberation, and Hustler Magazine v. Falwell, 103 HARv. L. REv. 601, 638-44, 660 (1990); Post, supra note 17, at 1133-36. 
Liberalism Divided suggests that we may have learned a bad lesson from that vindication. We may have learned that the route to reform is simply to enshrine our own (no doubt admirable) values in the state, even if by so doing we curtail essential processes of collective self-determination.

Ultimately, then, Liberalism Divided's celebration of the state reveals a tenuous and uncertain grasp on the value of democratic self-governance. Popular sovereignty has come to seem merely an impediment to the achievement of reform. That is a very high price to pay for the successes of the 1960s. It is in my judgment too high. Certainly we ought first to see if we cannot achieve further progress without adding to the bill.

The particular achievement of Liberalism Divided is to have presented an acute and astute perspective on the necessity for further reform. Although the book is not a reliable guide for how constitutionally to achieve this reform, it offers an unerring eye for the dysfunctional aspects of our present structure of communication. It articulates a forceful and memorable account of a progressive agenda for the next century. For this alone we owe Fiss a great debt. 


\title{
PROCESS VERSUS POLICY IN FOREIGN \\ RELATIONS: FOREIGN AFFAIRS AND THE UNITED STATES CONSTITUTION
}

\author{
Michael J. Glennon*
}

Foreign Affairs and the United States Constitution. Second Edition. By Louis Henkin. New York: Oxford University Press. 1996. Pp. lxxii, 582. \$29.95.

[T]he highest morality almost always is the morality of process.

\section{- Alexander M. Bickel ${ }^{1}$}

Reading the second edition of Louis Henkin's book brings to mind Frankfurter's reaction to Holmes' opinions: to quote from them, he said, is "to string pearls." 2 In style as in research, Foreign Affairs and the United States Constitution is a string of pearls. Elegant, graceful, and lucid, the book sets a standard for legal scholarship that is almost unmatched by current writers. Indeed, it recalls a bygone era of eloquence in legal writing, when authors wrote for the ages, and the best works resembled fine sculpture, with the moist clay carefully added, removed, and massaged to perfection. The carefully nuanced pages of Henkin's widely fêted work give the feel of a careful hand at work, smoothing the words and thoughts and massaging them until they are just right.

Louis Henkin, University Professor Emeritus at Columbia University, is a liberal internationalist. In writings that span four decades, he has argued for an active American involvement in international organizations, especially the United Nations; broadly protective international human rights initiatives; nonviolent, multilateral resolution of international disputes; and a free-flowing international interchange of commerce, people, and ideas.

Henkin is also a constitutionalist. He believes in nonprotean process, in a set of overarching rules that govern the allocation of decisionmaking power, and rules that do not vary depending on the desirability of the particular policy outcome to which they will lead in a given case.

* Professor of Law, University of Califomia at Davis School of Law. B.A. 1970, College of St. Thomas; J.D. 1973, University of Minnesota. - Ed.

1. Alexander M. Bickel, The Morality of Consent 123 (1975).

2. Felix Frankfurter, Mr. Justice Holmes and the Constitution: A Review of His TwentyFive Years on the Supreme Court, in MR. Justice HoLMES 46, 85 (Felix Frankfurter ed., 1931). 
During the New Deal and until the mid- to late-1960s, liberal internationalists favored a strong executive, weak Congress, and deferential judiciary. The Presidency, during that period, favored international engagement and nonconfrontational relations with the Communist Bloc. The United Nations was far more popular in the White House than on Capitol Hill. Congress, under the spell of southern segregationists, Senator Joseph McCarthy, and assorted other cold warriors, distrusted international institutions. The Bricker Amendment, a constitutional amendment proposed in 1953 that would have presumed all treaties to be nonself-executing, missed the required two-thirds majority by only one vote in the Senate. ${ }^{3}$ Congress strongly opposed admitting "Red China" to the United Nations, and, largely because of congressional concerns about being "soft on communism," détente with the Soviet Union was at least a decade away.

Vietnam, of course, changed all that. Liberal internationalists found powerful new friends in the Senate - Mansfield, Church, Fulbright, Cooper, Javits, Hatfield - counterpoised against an executive branch dominated by figures such as McNamara, Bundy, Rusk, Laird, and Kissinger that was increasingly willing to "go it alone." Executive and legislative perspectives differed dramatically on such things as the war, ABMs, MLRVs, covert CIA operations, and a military establishment perceived as overly influential by many in Congress.

Liberal internationalists were thus caught in a dilemma. They previously had favored broad executive power in foreign policy decisionmaking. They had wanted Congress to mind its domestic business and had wanted the courts to sit out whatever disputes might arise between the two. Now, though, the institutional tables had turned. Did they really prefer that the courts remain mute on Vietnam? Should Congress really remain passive while presidents used the military and CIA for possibly nefarious purposes? Did presidents really have unbridled power to commit the nation to defend countries with heinous human rights practices?

Some liberal internationalists responded to the dilemma simply by abandoning their earlier interpretation of the constitutional rules or by pretending to be consistent, but in fact stretched their analyses beyond recognition to get the results they desired. A few, constitutionalists to the end, subordinated policy to what they saw as preagreed process and accepted policy results incompatible with liberal internationalism.

It might be suggested that the real issue with the former group is whether they were right to be "principled" - i.e., sticking to pre-

3. See generally Gerald GunTHER, Constitutional LaW 206-07 (12th ed. 1991). 
ordained rules, or principles, whatever the outcome. Some of the law's great literature exalts this "neutral principles" approach. Fiat justitia et ruant coeli - "do justice though the sky falls." 4 Some will respond that this "formalism" overstates the law's determinacy and that legal rules are flexible enough to accommodate liberal internationalism. Others would go further and suggest that outcome is all there is and that the only task of the rules is to produce good policy - for Henkin, liberal internationalism - no matter how severely the decisionmaking process must be distorted to achieve that end. For the sky to fall, they might add, would be unjust.

Henkin does not fall into these latter categories. He does not not in Foreign Affairs and the United States Constitution, in any event - spell out a Grand Theory of Law that reconciles the law's indeterminacy with its universality. Still, if one were to locate Henkin on a spectrum stretching from formalist to realist to crit, it seems fair to say that he clearly is no crit, that he is reasonably open to the insights of legal realism, but that he nonetheless pays considerable worship to what Alexander Bickel called the "manifest" Constitution - provisions of the Constitution that are not opentextured and to which there attaches a moral obligation to obey. 5

Given this context, it ought to be interesting to see which prevails when Henkin's liberal internationalism runs squarely up against his commitment to constitutionalism. As I will try to point out, the answer is sometimes one and sometimes the other. If Henkin is unwilling to let all the constitutional firmament fall and cruish liberal internationalism completely, he is not averse to a letting a sizeable chunk crash down now and then.

I.

The first thing to be noted, again, about both Foreign Affairs and the United States Constitution and Henkin's first edition, Foreign Affairs and the Constitution, ${ }^{6}$ is that neither attempts a comprehensive, unified "field theory" that untangles and reweaves

4. The maxim traces to Lord Mansfield's judgment in Rex v. Wilkes, 4 Eng. Rep. 2527, 2562 (K.B. 1770).

5. See BICKEL, supra note 1, at 29-30. Bickel argued:

There is a moral duty ... for those to whom it is applicable - most often officers of government - to obey the manifest constitution, unless and until it is altered by the amendment process it itself provides for, a duty analogous to the duty to obey final judicial decrees. No president may decide to stay in office for a term of six years rather than four, or, since the Twenty-second Amendment, to run for a third term. There is an absolute duty to obey; to disobey is to deny the idea of constitutionalism, that special kind of law which establishes a set of pre-existing rules within which society works out all its other rules from time to time. To deny this idea is in the most fundamental sense to deny the idea of law itself.

Id. at 30 .

6. Louis Henkin, Foreign Afrairs AND the Constitution (1972). 
all of the disparate foreign affairs strands of the Constitution. Henkin presents no overarching analytic framework in which to evaluate the plenary and concurrent powers of Congress and the President and the role of the courts. Perhaps it would be asking too much to expect such a thing; those elements, after all, are sometimes unrelated, and an overarching theoretical explanation may be unattainable. A work addressing the theoretical underpinnings of foreign relations law might be a very different book. One of the most attractive aspects of Henkin's book is its readability and accessibility to nonexperts.

Still, other constitutional commentators as eminent as Henkin have ventured such approaches in constitutional terrain no less treacherous than foreign affairs, and not all of their attempts have been unintelligible. ${ }^{7}$ It would be interesting to read Henkin discuss some of the subterranean issues of foreign relations law, such as the relative merits of originalism and custom as interpretive guides, or other questions falling under the rubric of the "doctrine of sources."8 One need not glaze the eyes of a thousand readers with an extended exegesis on hermeneutics in order to explain the basic precepts that one accepts in interpreting the Constitution's foreign affairs powers. Nor is it hard to explain succinctly what law is and why it need be observed; indeed, Henkin has elsewhere done so himself with characteristic eloquence. ${ }^{9}$

Had Henkin attempted something of this sort, some inconsistencies might have been highlighted (or eliminated). But the short shrift accorded other topics would be more understandable, as would the fact that some conclusions are asserted more than they are developed.

Henkin's treatment of the President's foreign intelligence powers presents a curious example. Following a nuanced discussion of the war power, Henkin seemingly argues that intelligence activities, even those conducted overtly and directed solely at gathering information, are subject to congressional control (pp. 111-12). He justifies this conclusion on the ground that the President's intelligence gatherers are executing laws made by Congress. Congress passed the legislation that established the agencies and departments in question and in so doing necessarily spelled out what they can and cannot do. But because every federal employee necessarily traces his authority back to some congressional statute - the President having no power over the purse - that rationale would support a finding of congressional power to restrict any executive function and leave no room for the exercise of any exclusive presidential

7. See, e.g., John Hart Ely, Democracy and Distrust (1980).

8. For my own stab at it see Mrchael J. Glennon, Constitumional Diplomacy (1990).

9. See, e.g., Louis HenkIn, THE AGE of Righrs (1990). 
power in the realm of intelligence. Could the Congress order the repositioning of satellites to seek more intelligence on the environment and less on terrorism, or "task" the National Security Agency to break codes that the NSA had determined to be too well encrypted - and thus too expensive - to crack? Could Congress stop the President from using Foreign Service officers to attend parliamentary sessions in a foreign country to identify parliamentarians who might be open to recruitment by the CIA? Or, could Congress, prior to its authorization of force during the Persian Gulf War, have suspended the collection of all "humint" - human intelligence - against Iraq because Congress felt it was unduly risky?

Perhaps, but the answers hardly seem self-evident. A more subtle analysis of executive and legislative power over intelligence activities might consider a variety of other factors. These would include the extent to which the activity in question falls within the President's control as commander-in-chief or the congressional power over war, appointment, or appropriations; whether the activity in question violates international law; and the extent to which such activities have in the past been controlled by Congress. The frustrating answer is likely to be that intelligence activities are simply too varied to permit a generalized conclusion.

Further questions arise when Henkin's discussion of intelligence activities is read in juxtaposition with that dealing with the scope of Congress's power over the purse (p. 115). Henkin here confronts two of the Constitution's great paradoxes. First, if that power is indeed plenary, it must necessarily trump every executive power to which it might be applied. Congress would be able to deny funds for every presidential act in question, leaving no room for the exercise of sole presidential power. One is left to ask, however: By what principled analysis does Congress's exclusive power prevail over the President's?

Second is the matter of whether Congress's power over the purse is coextensive with its other substantive powers or extends beyond them. In other words, can Congress, by denying funds for a certain activity, reach conduct that it cannot reach by, say, exercising the war power? If the answer is that the powers are coextensive, the appropriations power would seemingly be read out of the Constitution as an independent check on presidential power. If, on the other hand, Congress can indeed pull the purse strings tight to reach executive conduct not amenable to regulation through the exercise of Congress's regular legislative powers, then we are back to the first question: Congress's power over the purse is in fact plenary - but why? 
Although he says otherwise, ${ }^{10}$ Henkin in fact resolves these dilemmas in favor of the presidency, but without explaining why. $\mathrm{He}$ writes:

Congress is required to appropriate funds for the activities of other branches of government that are within their independent constitutional authority. It is not free, for example, to refuse to appropriate funds to carry out treaty obligations, or independent decisions of the President. If Congress has authority under the Constitution to reject, regulate or terminate a Presidential activity it can do so by legislation or by refusing to appropriate funds (or by terminating funds previously appropriated). But what it cannot constitutionally regulate by legislation, it may not properly do by the exercise of any 'power of the purse.' [p. 115; footnote omitted]

He then adds this footnote:

To do so by withholding appropriations rather than by legislation engenders additional constitutional concerns, since legislation requires action by both houses, subject to president[ia]l veto, whereas withholding appropriations circumvents the President's veto and can be effected by one house of Congress refusing to approve an appropriation of funds. [p. $115 \mathrm{n}$.**]

It surely is "difficult to accept that the President should command a power expressly conferred upon Congress." Article I, section 9 of the Constitution provides that "No Money shall be drawn from the Treasury, but in Consequence of Appropriations made by Law."11 That section thus expressly denies the President access to the treasury without approval by both houses of Congress. No provision of the Constitution gives the President power to withdraw unappropriated funds to carry out plenary powers. The Supreme Court has never suggested as much. Presidents may on occasion have done so, or confronted Congress with a fait accompli that left it no alternative but to pick up the tab, but such incidents are not necessarily constitutionally acceptable.

Henkin's remarks on bicameralism and Chadha are perplexing. He seems to imply that Congress might, for example, have validly enacted a law prohibiting any use of force in Southeast Asia or requiring withdrawal of forces by a certain date, but that a refusal of the Senate to go along with funding the Vietnam War would have raised problems of bicameralism (pp. 125-28). Henkin cannot seriously mean that. That the approval of both houses of Congress is necessary for the enactment of a statute ${ }^{12}$ hardly implies that the

10. "The arguments for the Presidency reflect a fundamental misunderstanding .... It is difficult to accept that the President should command a power expressly conferred upon Congress." P. 114.

11. U.S. ConsT. art. I, $\$ 9$, cl. 7.

12. See INS v. Chadha, 462 U.S. 919 (1983) (invalidating provision of Immigration and Nationality Act that authorized either house of Congress to pass a resolution invalidating an executive branch deportation decision). 
inaction of one house, which impedes the implementation of the enactment, is unconstitutional. Legislation and appropriations are, in this context, on the same constitutional footing: neither takes effect without the President's signature, and since there is in effect no law if no appropriations bill is enacted, inaction by one house creates no Chadha problem. On the other hand, a Chadha problem would arise if a subsequent principle of international law were given effect over an inconsistent act of Congress - an act which Henkin, surprisingly, ${ }^{13}$ asserts would nonetheless control (p. 241).

II.

Notable tension emerges between Henkin the constitutionalist and Henkin the liberal internationalist concerning the issue of international law as U.S. law. The question, debated at length in 1986 and 1987 in the pages of the American Journal of International Law, 14 is whether the President can, without congressional approval, place the United States in violation of international law. Is it, for example, lawful for the President, acting alone, to mine the harbors of Managua, to detain an individual arbitrarily for a prolonged period of time, or to breach a treaty?

In the first edition, Foreign Affairs and the Constitution, Henkin seemed to answer in the affirmative. Henkin acknowledged that "[t]here are no clear Supreme Court holdings, or even explicit dicta, upholding the power of the President to act contrary to international law"15 but concluded nevertheless that the Constitution "does not forbid the President (or the Congress) to violate international law, and the courts will give effect to acts within the constitutional powers of the political branches without regard to international law."16

The issue came to court for the first time in 1986. In Garcia-Mir v. Meese, ${ }^{17}$ the Eleventh Circuit was asked to decide whether the executive acted constitutionally in detaining Cuban "boat people" in violation of international law. The third Restatement of the Law of Foreign Relations of the United States, of which Henkin was Chief Reporter, was then being drafted; its position on the issue closely tracked Henkin's in the first edition of Foreign Affairs and the

13. I say "surprisingly" because he earlier acknowledges that Congress can place the nation in violation of customary international law. See p. 235.

14. See, e.g., Jonathan Charney, The Power of the Executive Branch of the United States Government to Violate Customary International Law, 80 AM. J. INTL. L. 913 (1986); Michael Glennon, Can the President Do No Wrong?, 80 AM. J. INTL. L. 923 (1986); Louis Henkin, The President and International Law, 80 AM. J. INTL. L. 930 (1986); Jordan Paust, Is the President Bound by Customary International Law?, 81 AM. J. INTL. L. 377 (1987).

15. HENKIN, supra note 6 , at 460 n.61.

16. Id. at 221-22 (footnote omitted).

17. 788 F.2d 1446 (11th Cir. 1986). 
Constitution. The Restatement's most recent draft had said that the President, "acting within his constitutional authority, may [have the power under the Constitution to] act in ways that constitute violations of international law by the United States."18 Quoting this language, the court upheld the detention.

In the second edition of Foreign Affairs and the United States Constitution, Henkin criticizes Garcia-Mir v. Meese. He writes:

I do not believe the Attorney General (or the President) can disregard international law that is part of our law any more than he (or she) can disregard any other law. The court did not find that, as a result of some action within the President's constitutional power, the principle of international law against arbitrary detention had ceased to be a legal obligation of the United States. There was no suggestion that the President, acting under his constitutional power, had by executive agreement or executive order, made law that superseded the rule of international law forbidding arbitrary detention as domestic law. There was no suggestion that the President ordered the detention in the valid exercise of some independent constitutional authority as 'sole organ' or as Commander in Chief that might have effect as law in the United States. [pp. 244-45]

Only such acts, he suggests, can be given domestic legal effect in disregard of international law. Henkin here makes two arguments. First, the real problem in Garcia-Mir was not that the President placed the United States in violation of international law, but that he failed to say he was going to do so before he did it. The President needed, in other words, to make new law first, so as to supplant the otherwise controlling rule of international law that he proceeded to violate. Second, the court found the president's action permissible without determining, as a prerequisite, that he had been acting under his "sole organ" authority.

These distinctions chop logic. If the President had authority to place the United States in violation of international law, the Constitution could hardly require that the President first authorize his own act. The President is not required to announce an intention to abrogate other binding rules, such as executive orders. His order to perform an act authorizes the act. One prominent executive order, for example, prohibits assassination, 19 but - assuming that he has sole constitutional power to order an assassination - the President is free to ignore that order without proclaiming his intention to do so.

Moreover, the Garcia-Mir court necessarily found that the President acted within the scope of his constitutional power; its failure to say so explicitly may make its reasoning elliptical, but not

18. Restatement (THIRD) of Foreign Relations LaW of the UNITEd States $§ 131$ cmt. c (Tentative Draft No. 1, 1980).

19. Exec. Order No. 12,333, 3 C.F.R. 200, 213 (1982). 
untenable. To the contrary, Henkin is perplexing in his supposition that presidential "sole organ" power embraces the authority to place the nation in violation of international law. Typically, the concept of sole - or "exclusive," "inherent," or "independent" power is apposite not where, as here, the President acts in the face of congressional silence, but rather where the President acts in the face of congressional prohibition. ${ }^{20}$ Furthermore, the President demonstratively does not have exclusive power in this realm: Congress, in explicit terms, is given power "[t]o define and punish ... Offenses against the Law of Nations." 21

The confusion is heightened further in a footnote in which Henkin seems to take the opposite position that the President's "sole organ" power does not include the power to place the nation in violation of international law. Modifying his views, he writes: "International law is the law of the United States, and where international law forbids the use of force by the United States, such use of force would seem to be a violation of the President's constitutional duty to take care that the laws be faithfully executed" (p. 47 $\mathrm{n} . * *)$. If Henkin now believes these principles of international law nevertheless govern, why does he pointedly reiterate his 1972 position that the President "may take ... measures that are within his constitutional authority under his foreign affairs power even if they violate international law" (p. 242)? Does not the President almost always claim that a given use of force falls within his sole power? Is that not what the President necessarily claimed to have done in Panama, Grenada, and Haiti - and in Garcia-Mir? If the President is prohibited from placing the United States in violation of customary international law only if his act exceeds otherwise applicable constitutional limits, then the prohibition adds nothing to pre-existing constraints on executive power and merely diverts attention from the essential underlying question: Is the President's act constitutional? Henkin's approach - if this is his approach effectively reads customary international law out of any calculus of presidential foreign affairs powers; the hole of constitutional validity subsumes the donut of customary international invalidity.

One consequence of Henkin's inconsistency on this issue is that critics are given an easier target. Many other commentators have addressed the question, resulting in numerous and not easily reconcilable justifications for holding the President bound by the limits of customary international law. When piled atop Foreign Affairs and

20. Federal common law is, constitutionally, on the same footing as statutory law for separation-of-powers purposes. "All constitutional acts of power, whether in the executive or in the judicial department, have as much legal validity and obligation as if they proceeded from the legislature ...." THE FEDERALIST No. 64, at 190 (John Jay) (Roy P. Fairfield ed., 2d ed., John Hopkins Univ. Press 1981).

21. U.S. Const. art. I, § 8, cl. 10. 
the Constitution, those writings present an opponent of liberal internationalism with all the material necessary to set up a straw man and knock it down.

One prominent recent example is an article that appeared in the February 1997 issue of the Harvard Law Review, entitled Customary International Law as Federal Common Law: A Critique of the Modern Position.22 In it, Professors Bradley and Goldsmith take issue with those who see customary international law as limiting presidential foreign affairs power (and, it turns out, those who see customary international law as limiting just about any other governmental power, federal or state, executive, legislative or judicial). Adherents to the supposed "modern position," they tell us, believe that, because customary international law is federal common law, it is not inferior to statutes and that, when in conflict with a statute, it will govern if it is more recent; 23 that customary international law trumps inconsistent state law;24 and that it binds the President.25 Bradley and Goldsmith reject the "modern position" because it is grounded upon a misreading of, among other things, history, The Paquete Habana, ${ }^{26}$ Erie, ${ }^{27}$ Sabbatino, ${ }^{28}$ and democratic theory. Customary international law is thus not federal common law, and the President must observe customary international law only to the extent that Congress by law requires compliance. The principal target of their scorched-earth assault is Professor Louis Henkin.

A detailed response to Professors Bradley and Goldsmith's broad-ranging critique is unnecessary. Suffice it simply to note that their wholesale dismissal of "international law as our law" misses the mark on a number of counts, beginning with the notion that there exists a single, overarching "modern position" on the issue. As noted earlier, Henkin eschews any approach in the nature of a unified field theory of foreign relations law, preferring instead to analyze component issues one at a time. Now, confronted with one such field theory approach, the reason for his caution becomes apparent: the pieces don't fit together to make a single whole - at least, not as Bradley and Goldsmith try to do it. Bradley and Goldsmith fail in defining coherently what it is they reject, and

22. Curtis A. Bradley \& Jack L. Goldsmith, Customary International Law as Federal Common Law: A Critique of the Modern Position, 110 Harv. L. REv. 815 (1997).

23. See id. at 844 .

24. See id.

25. See id. at $844-46,861$.

26. 175 U.S. 677 (1900).

27. Erie R.R. Co. v. Thompkins, 304 U.S. 64 (1938).

28. Banco Nacional de Cuba v. Sabbatino, 376 U.S. 398 (1964). 
again in offering persuasive support for their ponderous one-sizefits-all thesis.

First, there simply is no single "modern position." The idea that international law is part of the law of the land is hardly modern, and its implications are hardly singular. As Bradley and Goldsmith point out, the words trace at least as far back as Blackstone. ${ }^{29}$ It is possible to create a single meaning of those words only by cobbling together the writings of numerous commentators and judicial opinions on multifarious aspects of the role of customary international law in domestic law, and only by overlooking the fact that no one commentator or court has ever advanced simultaneously the several propositions that Bradley and Goldsmith put forth as one. Surely no "majority" can seriously be claimed for the one position that they claim to be the modern one. With only a few exceptions, ${ }^{30}$ writers and courts have tended to focus on individual slices of the problem: Is the President bound by customary international law? Does the last-in-time doctrine apply as against statutes? Are the states bound? What rationale supports judicial legislating? How much federal common law survived Erie? Is interpretation of the Bill of Rights properly "informed" by reference to customary international law? Can customary international law be used to "find" additional fundamental rights? Henkin, in contrast to Bradley and Goldsmith, does not attempt to enlist for, say, individual rights analysis the same doctrinal support he has used in the separationof-powers context. Bradley and Goldsmith's article is a grand rehearsal of some of the arguments on such issues that have comprised this debate for two hundred years, but if a recataloguing is to be undertaken, the better approach is Henkin's. It's far too facile to suggest, as Bradley and Goldsmith do, that "lower federal courts have endorsed the modern position" 31 when in reality only parts of that "position" have been addressed individually by federal courts.

Second, Bradley and Goldsmith's assault on the "modern position" that they have invented collapses under scrutiny: theirs is mostly, on analysis, an attack not on the idea of customary international law as federal common law, but an attack on the idea of federal common law itself. True, the justification for judicial legislation - which is what federal common law is - is not self-evident, and, at least before Erie, its scattershot use, and abuse, was troublesome. However, a cogent contemporary rationale was provided, in City of Milwaukee $v$. Illinois, 32 by a jurist not commonly seen as a defender

29. See Bradley \& Goldsmith, supra note 22 , at 850 .

30. See, e.g., Jordan J. Paust, International Law as Law of the United States (1996).

31. Bradley \& Goldsmith, supra note 22 , at 821.

32. 451 U.S. 304 (1981). 
of the judicial activism that they eschew: Chief Justice William Rehnquist. The Chief Justice there defended federal common law as subject always to the "paramount authority of the Congress." 33 He suggested that Congress knows full well what the federal courts are doing, has not objected, and has therefore implicitly delegated to the federal courts the authority to make common law. While this may not be a complete answer to challenges to federal common law that flow from notions of democratic theory, it is at least sufficient to refute the assertion that federal courts are not constitutionally authorized to make foreign affairs judgments. Bradley and Goldsmith nonetheless argue that upon consideration of the modern position, "the justification for binding the political branches to judicial interpretations of [customary international law] vanishes." 34 To the contrary, once their supposed "principle" is considered, it vanishes. Numerous Supreme Court cases belie the claim. ${ }^{35}$ Banco Nationale de Cuba v. Sabbatino ${ }^{36}$ and its progeny, far from supporting the "principle," as they assert, ${ }^{37}$ flatly reject it: the Sabbatino court, remember, decided in favor of Castro's Cuba in the face of strenuous claims by the Kennedy Administration that to do so would violate international law, and act-of-state cases decided since Sabbatino have made clear that the courts would, and should, continue to make "foreign affairs judgments" even when a contrary judgment (nonapplication of the act-of-state doctrine) is urged upon them by the executive. ${ }^{38}$

\section{III.}

In any event, Henkin's ambivalence on the role of international law as domestic law leads to inconsistency on related issues, such as the presidential power to end, break, and interpret treaties, and the power of the President and the Senate to make non-self-executing treaties. Henkin resolves these issues as follows:

33. 451 U.S. at 313-14 (internal quotation marks omitted) (quoting New Jersey v. New York, 283 U.S. 336, 348 (1931)).

34. Bradley \& Goldsmith, supra note 22, at 861.

35. See, e.g., Dames \& Moore v. Regan, 453 U.S. 654 (1981); Youngstown Sheet \& Tube Co. v. Sawyer, 343 U.S. 579 (1952); Brown v. United States, 12 U.S. (8 Cranch) 110 (1814); Little v. Barreme, 6 U.S. (2 Cranch) 170 (1804).

36. 376 U.S. 398 (1964).

37. See Bradley \& Goldsmith, supra note 22 , at 861.

38. See, e.g., First National City Bank v. Banco Nacional de Cuba, 406 U.S. 759 (1972), in which six Justices reject the so-called "Bernstein exception," under which the Court would not apply the act-of-state doctrine when the executive expressly represents to the Court that its application would not advance the foreign policy interests of the United States. 
Termination. The President can terminate a treaty, i.e., he may bring a treaty to an end in accordance with its terms. ${ }^{39}$

Abrogation. The President can abrogate a treaty, i.e., he may bring a treaty to an end in violation of its terms. ${ }^{40}$

Breach. The President can decide to breach a treaty (p. 214).

Interpretation. The President cannot give a treaty a meaning other than the Senate's interpretation when it consented to the treaty. ${ }^{41}$ Nonself-executing treaties. Congress has a constitutional obligation to implement treaties made by the President and Senate (p. 210), and a treaty provision declaring that the treaty is nonself-executing is of doubtful constitutionality (p. 202).

The President's power to terminate a treaty without Senate or congressional approval is now generally accepted. In that situation the President acts in the face of Senate and congressional silence. Were the Senate or Congress to prohibit his act or to require - in a condition to the treaty or by statute - that a certain procedure be honored, the President would be bound to respect that limitation. Nevertheless, termination of a treaty in accordance with its terms does not violate the international law norm that requires good-faith compliance with a treaty, pacta sunt servanda, nor does it violate the President's duty to take care that the laws be faithfully executed. 42

The President's power to abrogate a treaty, or to breach a treaty, or to interpret it in a manner at variance with the Senate's understanding at the time of its consent, is different. In each of these circumstances, the President acts in the face of Senate opposition. His power is at its lowest ebb, and he can act only if he possesses exclusive power. ${ }^{43}$ Moreover, abrogation and breach each run afoul of international law. Still, Henkin fails to distinguish abrogation from mere termination, and insists, with no support in the case law and little analytic scaffolding, ${ }^{44}$ that the President is free to breach any treaty.

39. See p. 214. For example, President Carter terminated a mutual security treaty with the Republic of China in conformity with the treaty's provisions by giving the required twelve-months notice. See Goldwater v. Carter, 444 U.S. 996 (1979).

40. See p. 214. In Goldwater, the U.S.-R.O.C. mutual security treaty would have been abrogated, rather than terminated, had President Carter not given the twelve-months' notice.

41. See p. 206. For an account of the ABM treaty interpretation dispute, see GlenNoN, supra note 8 , at 134-35.

42. See generally GLENNON, supra note 8, at 145-61.

43. Cf. Youngstown Sheet \& Tube Co. v. Sawyer, 343 U.S. 579 (1952) (Jackson, J., concurring). Justice Jackson's analytic approach was adopted by the Court in Dames \& Moore v. Regan, 453 U.S. 654 (1981).

44. After having earlier restated his dislike for the political question doctrine, see p. 146, he does enlist it to support presidential power to act alone in breaching and abrogating treaties. "Courts," he writes, "do not sit in judgment on the political branches to prevent them from terminating or breaching a treaty." P. 214 (footnote omitted). 
As though this slalom were not arduous enough, Henkin adds a few more moguls at the bottom. While the President, in his view, can breach a treaty without congressional consent, he dislikes the power of Congress to place the United States in violation of a treaty. Although he acknowledges the longstanding power of Congress to enact laws inconsistent with U.S. treaty obligations (p. 211), Henkin apparently would prefer a different rule that would give force to a treaty even in the face of a subsequent inconsistent statute (p. 210). The reason, he writes, is the "anomalous" situation that results from the "constitutional obligation" of the Congress to implement treaties made by the President and the Senate (p. 210). Congress was purposefully denied any role in the process of negotiating treaties (p. 210). Thus it is, he reasons, unconstitutional for Congress not to pay the United States' treaty-incurred arrearages to the United Nations (p. 121). Suppose the President negotiates, and the Senate approves, a treaty that declares itself to be nonselfexecuting? That, Henkin concludes, would be "[a]nti-Constitutional' in spirit and highly problematic as a matter of law" (p. 202; footnote omitted). Specifically, Henkin states that it would be "against the spirit of Art. VI" (p. 202 n.**).

To some, it is Henkin's reading of the Constitution that might appear more anomalous: evidently he construes it as prohibiting presidential treaty violation with congressional support - when it comes, for example, to the nonpayment of UN dues - yet as permitting presidential treaty violation without congressional support. He himself, after all, recognizes the substantial role of the House in international agreement-making when he remarks that "[ $t]$ he constitutionality of the Congressional-Executive agreement is established" (p. 217 n.*); the House's initial exclusion from the treatymaking process, he reminds us, has not won the blessing of history. And while one would expect him to take sides in the two-centuriesold debate over whether a nonself-executing treaty constitutionally circumscribes the discretion of the House of Representatives to deny funding or other required support, Henkin might have pointed out that substantial authority opposes his view. As a matter of logic, it simply is not self-evident that the Constitution cunningly confers upon the House the paltry power to vote only one way, even if the issue is United Nations arrearages.

Henkin's current views on nonself-executing treaties are particularly noteworthy in light of his earlier writings. The seminal work on the Senate's power to declare a treaty nonself-executing - one of Henkin's finest articles, that in fact laid the groundwork for the first edition of Foreign Affairs and the Constitution - was The Treaty Makers and the Law Makers: The Niagara Reservation, pub- 
lished in the Columbia Law Review in 1956.45 In it Henkin demolishes the contention - of Philip Jessup, Oliver Lissitzyn, and Robert Moses, later adopted by the District of Columbia Circuit ${ }^{46}$ - that a reservation added by the Senate to a treaty with Canada was invalid. 47 Professors Jessup and Lissitzyn contended, as Henkin characterized their argument, that "the President and the Senate cannot control" the "domestic consequences of a treaty," and that "they cannot invite the Congress to join in the treaty process so as to prevent possible undesirable consequences from automatic interaction between the treaty and existing United States law."48 Henkin responded as follows:

[A]rticle VI establishes that the treaty power includes an important power to legislate domestically within a limited area.

... [A] provision requiring congressional implementation is inserted where without such provision the treaty would be selfexecuting, where under the Constitution the treaty would automatically become law of the land. Although such a treaty is "equivalent to an act of the legislature," the President and the Senate can prevent its automatic operation as the law of the land and hold up its effect until Congress acts. The treaty power is used, on such occasions, to give effect to the desire of the Senate and the President to offer a voice to the House of Representatives particularly where the treaty concerns an area of special concern to the Congress. ... [T] Senate have limited their automatic "legislative" power and shared it with Congress as a whole.

... A provision in the treaty that the whole treaty should not become effective until the Congress acted would be valid.

I suggest ... that the right to postpone the operation of a treaty for congressional approval or action is a recognized aspect of the treaty power and can be applied to any treaty provision ....

... [I]t may be most wise for the President and the Senate, when the situation suggests it, to ask Congress to join in making a treaty

45. Louis Henkin, The Treaty Makers and the Law Makers: The Niagara Reservation, 56 COLUM. L. REv. 1150 (1956).

46. See Power Auth. v. Federal Power Commn., 247 F.2d 538 (D.C. Cir. 1957), vacated as moot sub nom. American Pub. Power Assn. v. Power Auth., 355 U.S. 64 (1957). For Henkin's response, see Louis Henkin, The Constitution, Treaties, and International Human Rights, 116 U. PA. L. Rev. 1012 (1968). See also Louis Henkin, "International Concern" and the Treaty Power of the United States, 63 AM. J. INTL. L. 272 (1969).

47. The treaty made available to Canada and the United States additional amounts of water for hydroelectric power; the reservation provided that the share made available to the United States would not be available until legislation governing its use was enacted by Congress. See Convention Between the United States and Canada, Feb. 27, 1950, 1 U.S.T. 694, T.I.A.S. No. 2130.

48. Henkin, supra note 45, at 1164. 
provision effective.... The Constitution separated powers to prevent tyranny. Separation does not insist on conflict among the powers when the nation's interest begs their cooperation. ${ }^{49}$

The 1972 edition of Foreign Affairs and the Constitution yields nothing to the Jessup-Lissitzyn position. Henkin there firmly reiterates his view that the Niagara court "erred in refusing to give effect to the Senate "reservation."'50 "Parties to a treaty," he writes, "are presumably masters as to what they wish to agree to and what they consider an obligation." 51 Nor does the Restatement, over which Henkin presided, express any doubt about the incorrectness of Niagara. ${ }^{52}$ In the second edition of his book, Foreign Relations and the United States Constitution, however, Henkin has second thoughts and attempts to narrow the scope of his earlier claim. Referring to the Columbia Law Review article and the validity of the reservation in the Niagara Reservation Case, he writes:

I adhere to that view as regards that case, or any other special case where giving effect to a treaty as law might complicate the legislative process or have other highly undesirable consequences. But if what I wrote can be read to support a general policy of declaring all treaties, or a category of treaties, to be non-self-executing, I do not hold that view. [p. 477 n.100]

It is hard to see how what he wrote could be read that broadly though it is equally hard to read the Columbia piece as acknowledging that a reservation "that might complicate the legislative process or have other highly undesirable consequences" would be unconstitutional, and Henkin in 1996 gives no reason to suppose that it would be. To the contrary, the argument to support his current, narrower view seems "based on premises about the treaty power not articulated or examined." 53

One is left to ask why Henkin's thinking has moved in this direction on a key foreign affairs issue on which he first made his mark. The question is important: the practice of adding nonself-executing reservations has picked up in recent years, particularly with regard to human rights treaties, and variations on the theme have regularly worked their way into major arms control treaties. The answer, one might conclude, is that Henkin the liberal internationalist has, on this issue at least, won out over Henkin the constitutionalist.

49. Id. at $1169,1171-73,1182$.

50. HeNkIN, supra note 6, at 380 n.28.

51. Id. at 407 n.101.

52. See Restatement (Third) of Foreign Relations Law of the United States $\S 302 \mathrm{cmt}$. c and reporter's note 2 (1987).

53. Henkin, supra note 45 , at 1153. 
IV.

Henkin's many substantive footnotes and endnotes are a treasure trove of original historical research. Many, in fact, contain insights important enough to justify elevating them to the text. Navigating their lengthy, interconnected maze is reminiscent of wandering around lost in the tunnels beneath the Capitol. They are fascinating, but after a while, one forgets what is up above and ends up far from one's original destination. Would that an editor had sorted them out, placed like topics together, and relegated the notes to their traditional function of reference and support - rather than continuing the textual analysis in smaller type that burrows willynilly throughout the book. Would that Henkin had discussed, or at least mentioned somewhere in those labyrinthine notes, the important recent works of others that bear directly upon his analysis, such as William C. Banks and Peter Raven-Hansen's fine book, National Security Law and the Power of the Purse; Thomas M. Franck's provocative Political Questions/Judicial Answers; Jordan Paust's comprehensive International Law as Law of the United States; or Louis Fisher's widely praised Understanding Constitutional War Powers Today: Why Methodology Matters. And while a scholar of Henkin's stature may be granted an occasional ipse dixit in a work of such great significance and comprehensiveness, would that he had presented some support for a few factual assertions that appear incorrect. $54^{54}$

54. Henkin claims, for example, that the Bush administration relied upon the United Nations Security Council resolution authorizing use of force against Iraq to provide domestic, constitutional authority for waging war (p. 207). The Bush administration did assert extravagant power to wage full-scale war without congressional approval, and some commentators did seek to make the case that the Security Council's action rendered congressional approval unnecessary, but, so far as I can tell, the executive branch never joined in that wrong-headed theory. See generally Michael J. Glennon, The Constitution and Chapter VII of the United Nations Charter, 85 AM. J. INTL. L. 74 (1991); Michael J. Glennon, The Gulf War and the Constitution, ForEIGN AFF., Spring 1991, at 84. Henkin also claims that "[d]uring the quarter century since the [War Powers] Resolution was enacted, all Presidents have challenged its constitutionality" (p. 320 n.*). Again, not so. Contrary to the blatherings of the popular press - which regularly incants that error as a substitute for minimal research - Presidents Carter and Ford did not challenge the Resolution.

The State Department Legal Adviser during the Carter administration, Herbert Hansell, testified before the Senate Foreign Relations Committee in 1977 that the administration would "not challeng[e]" the validity of the Resolution. War Powers Resolution: Hearings Before the Senate Comm. on Foreign Relations, 95th Cong. 207 (1977) (statement of Herbert J. Hansell, Legal Adviser, U.S. Dept. of State). Later during that administration, the President's Counsel, Lloyd Cutler, wrote that the consultation requirement, section 3, was not triggered by the Iran hostage rescue mission, and added that if it had required advance consultation with Congress, "grave constitutional issues" would have resulted. SUBCOMM. ON IntL. Security and ScIENTIFIC Afrairs of the House Comm. ON Foreign AfF., 98th Cong., War Powers Resolution: Relevant Documents, Correspondence, Reports 50 (Comm. Print 1983) (legal opinion of May 9, 1980, by Lloyd Cutler, Counsel to Former President Carter, on War Powers Consultation Relative to the Iran Rescue Mission). There is no indication in the memorandum that Cutler was speaking for the administration. The Carter Justice Department, which asked for an opinion on the validity of the Resolution's 60 - 


\section{CONCLUSION}

Henkin's book is a critique of the process of foreign policy decisionmaking. It would be unfair to judge Henkin's success as a process critic by what he wants the process to produce. Everyone has preferences in that regard. The point of process is to ensure that certain people are, or are not, at the table; the point is not to guarantee or to forestall certain results. It is fair to ask, though, whether Henkin's idealized process is jury-rigged to promote liberal internationalism, whether Henkin respects the integrity of process or merely objects to disliked policy outcomes, and whether the process that he visualizes is internally consistent.

For the most part, the process prescribed by Henkin the constitutionalist does support the political outcomes supported by Henkin the liberal internationalist. Foreign Affairs and the Constitution has worn well in the quarter century since its initial publication in 1972. The reader might wonder how much Henkin's process criticism might have evolved if Congress had remained the branch of government most committed to liberal internationalism. The political situation has inverted dramatically over that turbulent period - when the first edition appeared, Richard Nixon was President and J. William Fulbright was Chairman of the Senate Foreign Relations Committee, replaced now by Bill Clinton and Jesse Helms. In a way, that reinversion has taken Henkin off the hook; his earliest predilections towards a strong executive and weak Congress are conducive, again today, to at least a wan form of liberal internationalism. How long that will last is of course anyone's guess. For years to come, though, under both Democratic and Republican administrations and Congresses, the second edition, Foreign Affairs and the United States Constitution, is likely to remain an indispensable starting point for research on the issues it addresses as well as a fascinating study in how a constitutional scholar of Solomonic stature reconciles preferred constitutional processes to occasionally incompatible policy preferences.

day time period, said: "The practical effect of the 60-day limit is to shift the burden to the President to convince the Congress of the continuing need for the use of our armed forces abroad. We cannot say that placing that burden on the President unconstitutionally intrudes upon his executive powers." Presidential Power to Use the Armed Forces Abroad Without Statutory Authorization, 4A Op. Off. Legal Counsel 185, 196 (1980). As for President Ford, although he filed the required reports following the Mayaguez incident and during the evacuations of Phnom Pen and Saigon, the President apparently has come to doubt the Resolution's validity after he left office. See generally GLENNON, supra note 8, at 93-96. The Clinton administration has been more disingenuous than most in its interpretation of the Resolution's strictures, see generally Michael J. Glennon, Too Far Apart: Repeal the War Powers Resolution, 50 U. MiAm L. REv. 17 (1995), but thus far it has not challenged the Resolution's constitutionality. 